\title{
Analysis of Methodological Approaches Towards Assessing Conditions of International Commodity Markets Convergence
}

\author{
By Alona Tanasiichuk ${ }^{1}$, Olha Hromova ${ }^{1}$, Oksana Yaremenko ${ }^{2}$, \\ Svitlana Kovalchuk ${ }^{2}$, Svitlana Sirenko ${ }^{1}$
}

\begin{abstract}
To analyze different methodological approaches to determining the marketing attractiveness of international markets and their convergence assessing. Develop an indicators system for assessing the convergence of international markets to determine their marketing attractiveness for domestic agricultural enterprises. The international markets have been rated on the basis of summing the ranks of indicators of attractiveness method of their business environment for Ukrainian farmers by the product group «1008 Buckwheat, millet and other cereals» in order to identify more favorable conditions for doing business. The application of this approach allowed to develop a target portfolio for further targeting the implementation of the internationalization strategy by domestic producers of the product group «1008 Buckwheat, millet and other cereals». The methodological basis of the study are general and special research methods: epistemological and systems analysis - in the study of «economic convergence» definition; systems theory and systems analysis - to analyze of process determining the marketing attractiveness of international markets and assessing their convergence; statistical analysis, synthesis and comparison - to identify trends in the entry of agricultural enterprises of Ukraine to international markets; comprehensive assessment of the convergence of agricultural enterprises of Ukraine under the conditions of international diversification. It has been proved that in the expert assessment of convergence indicators the markets of foreign countries, the indicators of which are as close as possible to the economy of Ukraine, should be singled out. It has been determined that the markets of Austria and Nigeria are promising for domestic agricultural enterprises, producers of the commodity group «1008 Buckwheat, millet and other cereals», with the possibility of overcoming a significant gap in certain indicators, namely: the market of Austria, Nigeria where there is low quality regulation and also unfavorable investment conditions. The scientific and methodological approach to the complex assessment of the convergence of new international markets for domestic agricultural enterprises under the conditions of international diversification has been substantiated and developed. The result of the evaluation allowed to come up to the conclusions about the marketing opportunities of domestic agricultural enterprises under the conditions of entering the markets of these countries. As a result of the proposed approach, it is possible to identify foreign markets that demonstrate favorable conditions for doing business in them, which indicates the presence of convergent conditions, which is a prerequisite for the entry of goods of domestic agricultural enterprises in the markets of these countries. As a result of the proposed approaches, there were identified new international markets, that demonstrated favorable conditions for doing business in them by domestic agricultural enterprises producing the product group «1008 Buckwheat, millet and other cereals». It has beed developed in the study a target portfolio for further targeting the strategy implementation of internationalization domestic producers of the product group «1008 Buckwheat, millet and other cereals».
\end{abstract}

Keywords: convergence, new foreign markets, enterprises, convergence evaluation of international market, marketing attractiveness of the agricultural market, the degree of convergence 


\section{Introduction}

Under the current conditions of globalization of economic activity there have been qualitative changes, the essence of which is that the participation of countries in world trade has reached a level where the international market ceases to be a complement to their domestic, and becomes a necessary condition for national economy and economic growth. The issues of economic development are relevant for a quantity of countries around the world, but in countries that undergone significant changes in the socioeconomic sphere during the most significant, because the total distance that was allowed then is quite impressive. Ukraine is no exception, whose rapid economic decline during its transformation was largely caused by a quantity of target and domestic factors that naturally hampered the country's transition to a market economy. Among the most significant economic decline are the following: «market unpreparedness» of society to perceive the core of economic reform, its grounds and establishments; the shortfall of a distinct and consecutive strategy for implementing reforms that would correspond to at least one of the models - either L. Baltserovich's «shock therapy» or J. Cornsch's gradualism. As a result, there was a kind of "mix", which is often called the post-Soviet model of development, but to identify its common features, the nature of relations in society and the sequence of transition from one to another stage of implementation is impossible due to differences in integration processes; quick increase of the shadow segment, increasing criminalization of economics; a great number of battles between definite economical groups in the early 1990s for the distribution of spheres of influence; significant increase in public debt, ineffective measures to improve the economy, inconsistency and non-transparency of reforms; significant energy dependence on exports, the presence of outdated technologies in the metallurgical, chemical and sugar industries, which proved to be the main consumers of energy; outflow of capital from Ukraine to numerous offshore zones. Thus, the problems of the national economy transformation proved to be much more complex than it was in developed countries.

\section{Literature Review}

A. R. Bedenkov (1998) detailed the question of the relevance of traditional marketing, and concluded that the reasons for the loss of its significance are: reducing the number of needs for which a corresponding product offer can be created quickly and efficiently; increasing the degree of internationalization and globalization of the economy reduces the need to expand the range of goods and services, focusing on one of the market segments, on a particular group of goods; market saturation leads to a reduction in the number of small producers and increased competition. Currently, there is increased competition between enterprises, which is expressed primarily in increasing marketing activity.

Indeed, if we go back to 1960, we can see that the ratio of world exports to global GDP was at $12 \%$, while today, according to the IMF, it is $30 \%$. At the same time, the balance in international markets is shifting in favor of the growing economies of developing countries. Today, developing countries are major business partners and new markets for each other. Developing countries over the past 40 years have increased their share in world 
sales from 33 to $45 \%$, sales between developed countries have increased from 8 to $26 \%$ of world sales of goods (2013).

However, developed countries still play a leading role in world trade, although their share decreased from 74\% to 55\% between 1990 and 2016 (according to the UN). The reason for this is that these states sell goods only among themselves. But in the near future, developed countries will be enriched by large-scale industrialization of developing countries and the formation in these countries of a well-off middle class of consumers who will adopt the Western development model (O. Bogomolov, 2012).

Regarding the essence and criteria for assessing the level of economic development (growth), there are no significant differences among the definitions of experts. V. Heyec' (2015). mentions that «Economic theory and practice, basically coincide in understanding, the concept of economic growth and, as a rule, associate it with an increase in gross domestic product (GDP) in real terms by volume, or in calculation. per capita».

It is important to emphasize the relationship between the goals of economic development of any country with its national characteristics.

After all, firstly, according to a fundamental study by Nobel Prize winner Douglas North in 1996, each country has a «strictly defined set of formal and informal institutional constraints» (2000). In its turn, these restrictions will affect the formation of economic development goals. Therefore, in a transition economy it is impossible to copy the experience of developed countries in the context of regulations and informal rules of business conduct of business participants (agreements, contracts, voluntarily assumed rules of conduct, unwritten codes of ethics, professional consciousness, dignity, etc.). It is also worth while noting that formal institutions can be changed much faster than informal ones, which involve changes in generations. Therefore, in the domestic economy one cannot expect effective action of market laws, even carefully copied from the regulations of developed countries, as they will not comply with the informal «rules of the game» of this society.

Secondly, the goals of economic development of each country, including Ukraine, depend on the specific stages and conditions of this development. An example is the situation in Ukraine during the deep crisis in 1990-1995, when annual inflation exceeded $200 \%$, and in 1993 was a record 256\% (2003). At this stage, the goal of the country's economic development was to overcome the crisis and financial stabilization. The situation is quite different from 2000 to 2008, when the economy gained significant growth rates exceeding $5 \%$ of GDP. Usually in this case there are alternative options for justifying the goals of economic development: raising living standards, renewal of fixed capital, etc.

Studies of economic processes dynamics in Ukraine in 2008-2014 allow us to conclude that the economy was in crisis. The significant deterioration of the economic situation from 2014-2019 is due to the conduct of hostilities in eastern Ukraine, which caused a chain reaction of imbalances in all macroeconomic indicators. Among the main factors determining economic trends in 2015 are: low external and domestic demand due to the slowdown in economic growth; reduction of the purchasing power of the population due to the reduction of real incomes; complicating relations with major trading partners and the outflow of investment. In 2014, there was a significant acceleration in the rate of industrial production decline, which amounted to $10.2 \%$ by the end of the year. Negative dynamics was shown by all major aggregate industrial activities: reduction of production 
in the mining and quarrying industry was $13.7 \%$, processing industry $-9.3 \%$, electricity, gas, steam and air conditioning supply - 6.6\%. This trend was largely due to falling production in Donetsk and Luhansk regions (by 31.5\% and 42\%, respectively, in 2014). As a result, GDP declined by 6.8\% in 2014, continued to decline in 2015, and in 2016 alone, GDP grew by $2.3 \%$. The complex interaction of indicators in the absence of appropriate measures to stabilize the situation has led to increased processes of econom1ic decline (O.Kovin'ko, 2017).

Under modern economic conditions, the urgent problem is to overcome the uneven economic development of Ukraine, which is confirmed by the processes of convergence and divergence of its economic space. The tasks of economic growth of the country must be solved in conjunction with the economic aspects of spatial development, this is of practical importance. By the way, the very concepts of «convergence» and «synergy» (convergo - converge; convergence - approach, converge; synergy - cooperation, commonwealth) are surprisingly similar, which suggests the existence of a direct connection and interdependence between the level of unification; efforts and the level of effect, which in this case will exceed the effect of separately operating entities (A.Tanasiichuk et al., 2020).

There are two interrelated but not identical concepts of convergence that determine the different effects of economic policy: $\alpha$-convergence and $\beta$-convergence. The first involves reducing the inter-market differentiation of gross domestic product (GDP) per capita or other income indicators. The second is the result of the accelerated development of poorer regions, which leads to a gradual smoothing of inter-market asymmetries (L.Korol'chuk, 2012).

Consider the types of changes in the case of convergence (coinciding), which were considered in the works of Barro, D. Kwa, AM Kolota, Lucas, D. Lukyanenko, G. Menkyu, Michal G. Wozniaka, A.Lieutenant, P.Romero, Fr.Sala-i-Martina, Ya.M. Stolyarchuk, V.Chuzhikova (2013) (Fig. 1):

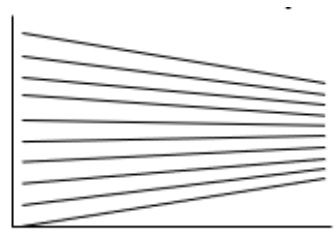

a - absolute

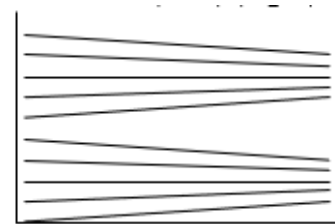

b - club

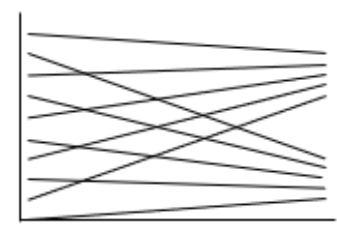

c - conditional

Fig. 1. Types of convergence

Source: developed by the author

1. Absolute convergence (absolute coinciding, unconditional coinciding) - the values of economic development levels of different regions (countries, markets) in the long run approach each other regardless of their initial value and differences in the structural parameters of their economies.

2. Club convergence (club of coinciding)-the values of levels of development (countries, markets), which have not only similar economic structures, but also close initial values of economic development levels in the long run are close to each other. Such regions 
(countries, markets) form clubs of convergence.

3. Conditional convergence (conditional coinciding)-the value of economic development levels of regions (countries, markets) that have similar parameters of economic structure (advantages, technologies, population growth, public policy, market conditions, legal restrictions, etc.), in the long run plans approach each other regardless of the initial value. Conditional convergence implies the convergence of countries' economies to their own stable positions, and the most stable provisions can differ significantly, and even diverge over time, so this trend may well be combined with both general (unconditional) convergence and general divergence, which is enough convincingly confirmed empirically (Barro et al., 1992), (G.Mankiw et al., 1992). It all depends on the mutual location of the initial and stable positions of the economies. These two types of convergence are analyzed in the literature within the framework of the so-called P-convergence approach.

The convergence of countries is well reflected in indicators of real GDP growth and GDP per capita, as well as indicators of investment, unemployment and inflation. Our choice of indicators of variable macroeconomic studies of convergence follows from the following reasons (O. Kovin'ko, 2016) (Fig. 2):

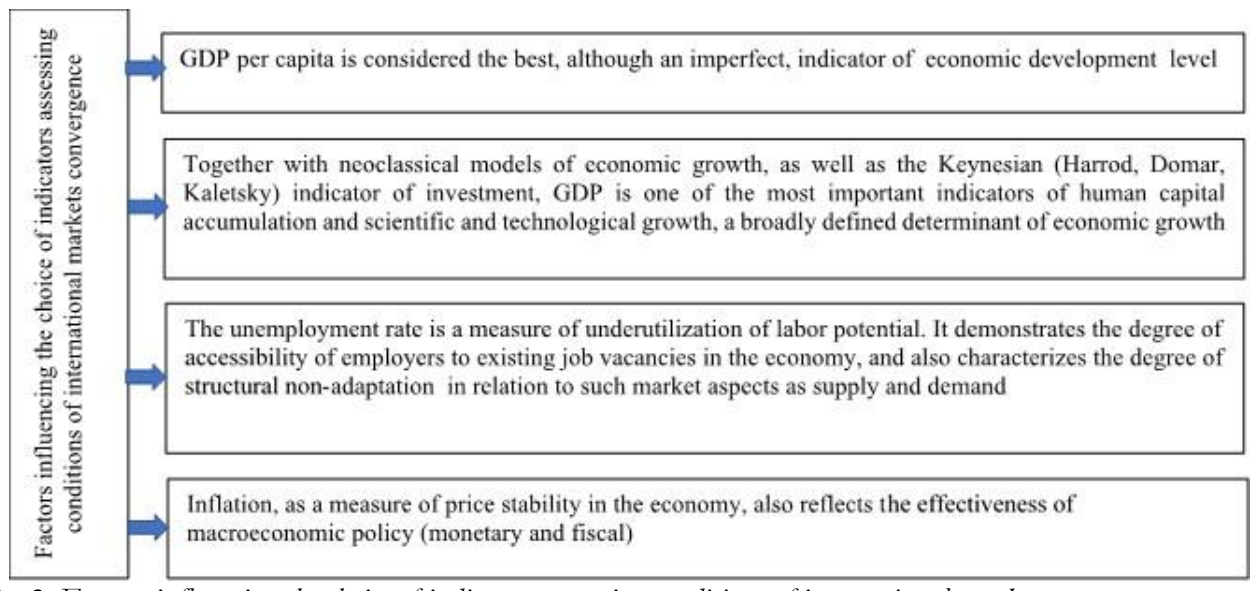

Fig. 2. Factors influencing the choice of indicators assessing conditions of international markets convergence Source: developed by the author

Consider the types and indicators for estimating the rate of convergence between countries and between markets within countries using different approaches presented in the reviews of Barro and Ks. Sala - i - Martin, S. Durlaf and D. Kwa (1992), (1999).

One of the results of the analysis of the world shows that with significant convergence among developed countries (including the Organization for Economic Co-operation and Development, which unites 34 countries, most of which are high-income countries and high human development index (OECD), the general inequality of the world remains and even progresses. The fact is that richer countries form one club (cluster) of convergence, developing countries-another one. This phenomenon is called in the literature «Twin Peaks» (two-peak distribution). And here we can note the combination (coexistence, overlap) of two trends: general divergence with local convergence (J. Robert Barro et al., 1992) (S. Durlauf et al., 1999). 


\section{Results of the Study}

To analyze different methodological approaches to determining the marketing attractiveness of international markets and their convergence assessing. Develop an indicators system for assessing the convergence of international markets to determine their marketing attractiveness for domestic agricultural enterprises.

The approach to assessing the differentiation of market types is based on comparing the growth rates of the markets of leading countries and outsider ones. Thus, if poorer countries tend to have higher growth rates than rich ones, then theoretically after some time the gap between rich and poor should narrow, and in this case it is said that there is convergence, convergence, approaching indicators to some common value, and therefore reduction of differentiation. This approach refers to the neoclassical model of growth and is widely used in the analysis of convergence (coinciding) (J. Robert Barro et al., 1992), (Sala-i-Martin X., 1996). Its advantage is that it is possible to determine the rate of convergence, as well as to make a forecast. There are absolute convergence and conditional one.

The parameters of absolute convergence are determined within the growth model and are calculated as a result of econometric estimation of the regression model. The classical model for measuring convergence, proposed by R. Barro and KS Sala-i-Martin, is as follows (1992), (1999):

$\frac{1}{T} \ln \frac{y_{t+\tau}}{y_{t}}=\alpha-\frac{\left(1-e^{\beta t}\right)}{T} \ln \left(y_{t}\right)+\varepsilon$

where ut-GDP per capita in the study period, $t$,

$\mathrm{T}-$ is the period of time in which the process of convergence is considered,

$\mathrm{E}$ - is the basis of the natural logarithm,

$\alpha, \beta$ - estimated parameters from the regression model,

$£$ - regression errors.

The model establishes a relationship between the average annual growth rate (left side of the equation) and the initial value of GDP (in logarithms) - the second term of the right side of the equation.

The hypothesis of convergence (coinciding) is accepted if the statistical value of the parameter is bigger than zero. In this case, for this group of countries, the GDP growth rate and the value of GDP at the beginning of the period is inversely related (Fig. 3.).
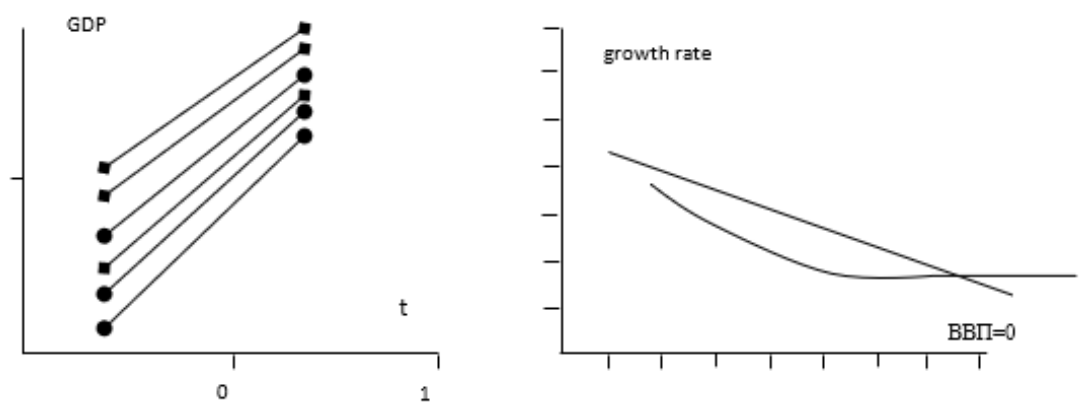

Fig. 3. Estimation of convergence within the model of $\beta$ - convergence

Source: developed by the author. 
The parameter $\alpha$ characterizes the long-term steady state of the economic process, to which, according to the neoclassical model of growth, countries should approach. If the estimate is $\beta<0$, the reverse process-divergence is observed.

A negative value of the coefficient at the right side of equation (2.1) means that there is a tendency to equalize the values of average income per capita: less developed countries (with less) have an average higher growth rate, ie catch up with developed countries (denoted as «catching up - catches up»). Equation (2.1) itself defines the function (more precisely, the logline approximation) of some representative country (market) approach to a state of stable equilibrium under the assumption that the rate of convergence due to the value of the parameter $\beta$ is constant.

The rate of convergence shows how many percent per year the distance between the representative country (market) and the long-run equilibrium value decreases. With absolute convergence, all values of GDP in the long run (if true, then in the infinite future) converge to one (equilibrium) level, and the distance between the representative market and the steady state becomes zero.

The decrease in the distance between the representative market and the steady state is due to the reduction of the differences between the values of the markets on average, in the same proportion. Thus, the speed of approximation of a representative market to a stable position at the same time acts as an assessment of the rate of reduction of differences between countries (markets).

However, with significant fluctuations (shocks), i.e. deviations of the values of countries (markets) from the group average (which acts as a representative value of the country (market)), the variation between regional values may increase, while the average approaches to a stable state. To put it in a few words, the existence of absolute $\beta$ convergence, as noted by the authors of this approach, is a necessary but not sufficient condition for the existence of a-convergence (E. Novitskiy, 1999). In other words, the presence of $\beta$-convergence does not mean a decrease in variation (for example, measured by the coefficient of variation). Such situations, when $\beta$-convergence is detected in the absence of a-convergence, are quite real, even for two countries system.

Besides the absolute, there is a conditional $\beta$-convergence, which characterizes the general trend of convergence of economies, each to its own stable level. The parameters of the conditional $\beta$-convergence process are estimated on the basis of model (2), which differs from model (1) in addition.

To test the hypothesis of conditional convergence in the growth model, it is necessary to take as a constant the level of stable equilibrium for each individual economy. One of the methods is to introduce into the regression equation additional variables growth of structural type (to some extent determine the structure of the economy features), which would be characteristics (as they say, proxy) of the income level in a stable state:

$\frac{1}{T} \ln \left(\frac{y_{1+\tau}}{y_{t}}\right)=\alpha-\frac{\left(1-e^{-\beta \tau}\right)}{T} \ln \left(y_{t}\right)+\gamma S_{t}+\varepsilon$

The positive coefficient $\beta$ characterizes the process of conditional $\beta$-convergence. Using this approach, Barro, Fr. Sala-i-Martin (1992), G. Menkew, P. Romer, and D. Weil (1992) have clearly confirmed the hypothesis of conditional convergence of data across the world. Regarding the rate of convergence, it should be said that in this case the parameter $\beta$ 
characterizes the (average) rate of approximation of economies to their stable state (each to its own stable state), and can not be considered a measure of their convergence, as stable positions can differ significantly (in including in the dynamics). Therefore, the convergence of economies to them may be accompanied by a marked increase in differentiation, which, in our opinion, will be a prerequisite for the entry of goods from some countries to new markets in foreign countries.

The third approach considers the dynamics of changes in the function (density) of the distribution of values of the indicator, to some extent combines the advantages of $\beta$ convergence and $\sigma$-convergence. In this case, the conclusion about the trends of differentiation may be more detailed, taking into consideration the characteristic changes in the distribution. This approach was proposed in the works of D. Kwa and was called "distribution dynamics (Dynamics of distribution)" (S. Durlauf. et al., 1992), (D. Quah, 1993).

It allows, after assessing the structural characteristics of the distribution at the start and conclusion of the phase, to determine the change dynamics in the structure based on an assessment of the dynamics (movement of countries) within the distribution. A significant advantage of this approach is that it makes it possible to obtain a (long-term) distribution forecast, i.e., the form, differentiation structure in the future. It is with this approach that D. Kwa substantiated the two-peak perspective distribution of income in the world ("twin peaks)", i.e., the tendency to increasingly confident division of countries into rich and poor. $\mathrm{I}_{\mathrm{i}}=\sum \mathrm{a}_{\mathrm{ij}} \mathrm{z}_{\mathrm{ij}}$

where aij- weighting factors, that define the standard of collaboration of the $j$-th pointer to the consolidated pointer; zij - standardized merits of input pointer xij.

In this approach, a larger value of the indicator corresponds to a greater divergence of indicators between countries (divergence), with convergence - the distance of indicators should be minimal.

Summarizing the results of research of domestic and foreign scientists, we note that they all agree that to assess integration processes will effectively use statistical information of quantitative and qualitative nature, which in the process of collection and analysis are grouped into a common system of economic integration indicators and allow to estimate the degree of convergence of the studied structure (Robert Barro et al., 1992), (S. Durlauf et al., 1992), (G. Walldorf, 1992).

Based on the results of the research, a scientific approach to the application of marketing analysis of trade integration relations in the activities of agricultural enterprises has been formed, which, in contrast to existing practices, provides for the analysis of trade integration relations according to the relevant indicators.

1) agricultural products share in world sales;

2) the trade balance value;

3) annual increase in imports of foreign markets;

4) the distance between Ukraine and partner countries;

5) partners concentration in the foreign market and identification of specific foreign markets taking into account the formed market portfolio of the enterprise, opportunities and threats for domestic agricultural enterprises in the markets of selected countries; strengths and weaknesses of their own production and marketing activities.

The application of this approach has been proposed for the development of the target 
portfolio of international activities and further targeting of the international diversification strategy implementation by agricultural enterprises of Ukraine.

The needs of the domestic market in grain products are fully met today,, as the production base allows to process different types of grain crops. Ukraine is simultaneously ranked among the world's largest producers and the world's largest importers of buckwheat. According to 2019 data, Ukraine ranks 3rd in production and 4th in buckwheat imports. The reason for this situation was the formed culture of buckwheat consumption in Ukraine with a simultaneous reduction in its production. Over the past 10 years, buckwheat production has decreased 4 times to 104 thousand tons in 2020 [25].

Currently, Ukrainian farmers prefer to grow more profitable and export-oriented crops (wheat, corn, sunflower, etc.). Especially since they are in serious competition with cheaper buckwheat.

Having analyzed the dynamics of production of the product group "1008 Buckwheat, millet and other cereals" in Ukraine, we see that the volume of buckwheat production in 2020 is $27.9 \%$ less than in 2018 , but increased by $17.2 \%$ compared to production in 2019 (table 1).

Table 1: Production volumes dynamics of the commodity group "1008 Buckwheat, millet and other cereals" by farms of all categories, 2018-2020

\begin{tabular}{|l|c|c|c|c|c|c|c|c|}
\hline & \multicolumn{3}{|c|}{$\begin{array}{c}\text { harvested area, } \\
\text { thsd.ha }\end{array}$} & \multicolumn{3}{c|}{$\begin{array}{c}\text { volume of } \\
\text { production, } \\
\text { thsd. centner }\end{array}$} & \multicolumn{2}{c|}{$\begin{array}{c}\text { Deviation of } \\
\text { volumes } \\
\text { production, } \%\end{array}$} \\
\hline & 2018 & 2019 & 2020 & 2018 & 2019 & 2020 & $\begin{array}{c}2020 / \\
2018\end{array}$ & $\begin{array}{c}2020 / \\
2019\end{array}$ \\
\hline Yкpaïнa & 106,4 & 65,2 & 81,6 & 1443 & 887 & 1040 & $-27,9$ & 17,2 \\
\hline Vinnytsya & 7,5 & 4,8 & 6,7 & 117,6 & 74,0 & 94,8 & $-19,4$ & 28,1 \\
\hline Volyn & 2,3 & 1,3 & 1,5 & 24,2 & 14,3 & 16,0 & $-33,9$ & 11,9 \\
\hline Dnipropetrovsk & 1,2 & 0,5 & 0,7 & 10,5 & 5,0 & 3,8 & $-63,8$ & $-24,0$ \\
\hline Donetsk & 4,7 & 3,8 & 4,0 & 33,0 & 38,7 & 15,8 & $-52,1$ & $-59,2$ \\
\hline Zhytomyr & 19,3 & 14,3 & 15,6 & 283,0 & 197,1 & 183,5 & $-35,2$ & $-6,9$ \\
\hline Zakarpattya & 0,5 & 0,2 & 0,1 & 3,1 & 2,0 & 0,7 & $-77,4$ & $-65,0$ \\
\hline Ivano-Frankivsk & 1,3 & 0,8 & 0,8 & 16,7 & 8,8 & 8,6 & $-48,5$ & $-2,3$ \\
\hline Kyiv & 6,3 & 3,3 & 4,2 & 108,4 & 51,0 & 65,8 & $-39,3$ & 29,0 \\
\hline Kirovohrad & 1,9 & 0,8 & 1,3 & 22,1 & 12,2 & 12,2 & $-44,8$ & 0,0 \\
\hline Luhansk & 0,4 & 0,2 & 0,3 & 2,6 & 3,9 & 2,2 & $-15,4$ & $-43,6$ \\
\hline Lviv & 3,2 & 1,9 & 2,7 & 40,5 & 22,7 & 32,8 & $-19,0$ & 44,5 \\
\hline Mikolayiv & 3,1 & 2,6 & 2,9 & 31,5 & 32,6 & 20,9 & $-33,7$ & $-35,9$ \\
\hline Odesa & 0,5 & 0,1 & 0,4 & 4,7 & 1,1 & 1,9 & $-59,6$ & 72,7 \\
\hline Poltava & 3,5 & 1,9 & 2,2 & 46,7 & 17,5 & 26,1 & $-44,1$ & 49,1 \\
\hline Rivne & 2,8 & 2,1 & 2,3 & 44,0 & 34,9 & 36,9 & $-16,1$ & 5,7 \\
\hline Sumy & 10,9 & 4,8 & 7,5 & 127,7 & 74,4 & 129,7 & 1,6 & 74,3 \\
\hline Ternopil & 6,4 & 5,6 & 5,3 & 93,4 & 65,9 & 77,2 & $-17,3$ & 17,1 \\
\hline Kharkiv & 8,7 & 5,5 & 6,5 & 111,5 & 62,5 & 69,1 & $-38,0$ & 10,6 \\
\hline Khmelnytskiy & 11,6 & 6,9 & 9,3 & 213,9 & 132,1 & 168,6 & $-21,2$ & 27,6 \\
\hline Cherkasy & 1,2 & 0,5 & 0,9 & 20,3 & 6,5 & 11,4 & $-43,8$ & 75,4 \\
\hline Chernihiv & 8,6 & 3,0 & 5,8 & 79,3 & 25,7 & 53,8 & $-32,2$ & 109,3 \\
\hline Other regions (confidential information) & 0,5 & 0,3 & 0,6 & 8,3 & 4,1 & 8,2 & $-1,2$ & 100,0 \\
\hline Soura:
\end{tabular}

Source: developed by the author on the basis of [14] 
According to the classifier of foreign economic activity, buckwheat is included in group 10 «10 Cereals» and in commodity subheading number 1008, «1008 Buckwheat, millet and other cereals».

Commodity group «1008 Buckwheat, millet and other cereals» is one of the main crops, the value of which lies in the great variety of its useful properties and a wide range of applications.

The carried out analysis of sown areas of the commodity group «1008 Buckwheat, millet and other cereals» by farms of all categories in 2018-2020 by region allowed us to conclude that the buckwheat market in Ukraine in 2019 fell considerably, and in 2020 it began to fall sharply to develop since the area of sown areas increases. Thus, comparing year 2020 to 2019 , the area increased up to $25 \%$, and due to it increases the amount of harvest, which in 2020-2021 will reduce imports of buckwheat and increase exports of this product.

According to the Trade map website, in 2019 Ukraine took 2nd place after the United States in the export of the commodity group «10 Cereals» and 15th place in the export of the commodity group «1008 Buckwheat, millet and other cereals», which covers $1.6 \%$ of the world exports, and in natural measurement is 55,196 tons. The average distance to the markets of importing partners is $2751 \mathrm{~km}$, and the concentration of exports is 0.08 .

In terms of world leadership, the 1st place is occupied by Peru with an export share of the product group "1008 Buckwheat, millet and other cereals" 13\% and a value of 135,964 thousand dollars, 2nd - 3rd place in the ranking of buckwheat exporting countries - USA and Canada, respectively. $13.4 \%$ and $11.4 \%$ of world exports and the value of 115,528 thousand dollars and 108,635 thousand dollars [26].

Activity of agricultural enterprises of Ukraine international activity in 2019 is impressive, because the export of Ukrainian buckwheat comes to 59 markets. The largest share of exported products to Ukraine is on the market of Poland - 18.8\%, Germany - 11.3\%, which in value terms is 3076 thousand dollars and 1842 thousand dollars.

The third place is occupied by the market of the Netherlands $(8.2 \%)-1345$ thousand dollars, the fourth place belongs to the market of South Africa, which exports $7.4 \%$ of Ukrainian buckwheat. The next step is England (7\%) - 1143 thousand dollars, and the sixth place is occupied by the partner-importer - the Italian market, which exports buckwheat for 947 thousand dollars.

Having analyzed the volume of imports of the product group «1008 Buckwheat, millet and other cereals» in 2019, the main leaders-importers in the world market, concluded that in the studied markets there is demand for agricultural products, in particular for the product group «1008 Buckwheat, millet and other cereals» (fig 4). 


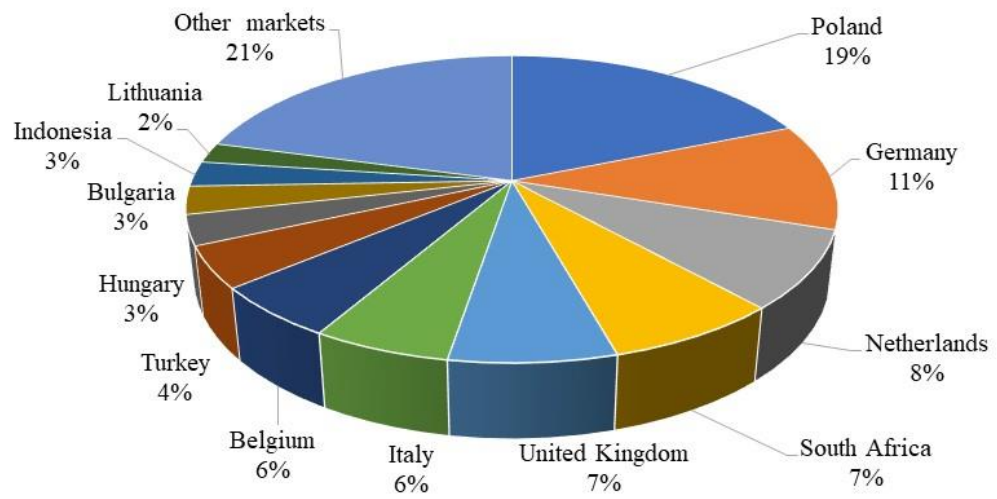

Fig. 4. Volumes of Ukrainian imports of the commodity group «1008 Buckwheat, millet and other cereals» to the world's leading importing markets, 2019,\%

Source: developed by the author on the basis of [26]

Since there is a tendency in Ukraine to increase production of the product group «1008 Buckwheat, millet and other cereals», it is necessary to look for new international markets and links for export activities.

Segmentation of foreign markets is carried out according to the criterion «Share in world imports of the commodity group» «1008 Buckwheat, millet and other cereals».

Segment A includes markets, the share of the product group «1008 Buckwheat, millet and other cereals» in world imports is from 1 to $25 \%$, the markets of segment B - the share of the product group «1008 Buckwheat, millet and other cereals» in world imports is from 0 up to $1 \%$, and the markets of segment B - the share of the product group «1008 Buckwheat, millet and other cereals» in world imports is $0 \%$.

So, in 2019, segment A includes the markets of 18 countries, 12 of which Ukraine exports the product group «1008 Buckwheat, millet and other cereals» the markets of Germany, the Netherlands, Belgium, France, Italy, England, Poland, Indonesia, Australia, UAE, China and Spain. Other markets in 6 countries should be considered as potentially new international markets for the sale of Ukrainian buckwheat, including the markets of the United States, Canada, Japan, Brazil, Austria, and Nigeria. Segment B has markets in 77 countries: Iran, Latvia, Spain and others. Other markets in 100 countries belong to segment B.

In our opinion, the promising markets for export activities of Ukrainian enterprises are the countries of group A, namely those 6 countries in which there is a demand for the product group «1008 Buckwheat, millet and other cereals» (table 2).

Table 2: Indicators of marketing attractiveness of new international markets for Ukraine by product group «1008 Buckwheat, millet and other cereals», 2019

\begin{tabular}{|l|c|c|c|c|c|}
\hline Countries & $\begin{array}{c}\text { Share in world } \\
\text { imports, } \%\end{array}$ & $\begin{array}{c}\text { Trade } \\
\text { balance in } \\
2019\end{array}$ & $\begin{array}{c}\text { Annual increase } \\
\text { in import value, } \\
2017-2019\end{array}$ & $\begin{array}{c}\text { Concentration of } \\
\text { supplier } \\
\text { countries }\end{array}$ & $\begin{array}{c}\text { Average distance } \\
\text { between the } \\
\text { countries, } \mathrm{km}\end{array}$ \\
\hline USA & 12,7 & -3366 & -4 & 0,3 & 5405 \\
\hline Canada & 4,2 & 68878 & -5 & 0,24 & 5927 \\
\hline Japan & 4,1 & -37960 & -8 & 0,29 & 7227 \\
\hline
\end{tabular}




\begin{tabular}{|l|c|c|c|c|c|}
\hline Countries & $\begin{array}{c}\text { Share in world } \\
\text { imports, } \%\end{array}$ & $\begin{array}{c}\text { Trade } \\
\text { balance in } \\
2019\end{array}$ & $\begin{array}{c}\text { Annual increase } \\
\text { in import value, } \\
2017-2019\end{array}$ & $\begin{array}{c}\text { Concentration of } \\
\text { supplier } \\
\text { countries }\end{array}$ & $\begin{array}{c}\text { Average distance } \\
\text { between the } \\
\text { countries, } \mathrm{km}\end{array}$ \\
\hline Brazil & 2,2 & -19185 & 2 & 0,32 & 4854 \\
\hline Austria & 1,5 & 177 & -1 & 0,14 & 4171 \\
\hline Nigeria & 1,4 & -13356 & 41 & 0,4 & 8884 \\
\hline
\end{tabular}

Source: developed by the author on the basis of [26]

The trade balance of the studied markets is negative, except for the markets of Canada and Austria, which means that countries spend more on imports of goods than they receive from exports of their goods, ie the ratio of exports to imports is lower 1.

The annual increase in import value for the studied product group reflects the growth of turnover, i.e. there is a trend of growth of imports of the product group «1008 Buckwheat, millet and other cereals» in Nigeria - 41\%, Brazil - 2\%. The decrease in import turnover is observed in the US markets - 4\%, Canada - 5\%, Japan - 8\%, Austria - 1\%.

High intensity of competition (the coefficient is approaching one) is not observed in the studied markets. The average intensity of competition is present in the markets of Nigeria, USA, Canada, Japan, Brazil with a rate of $0.4-0.24$. In the Austrian market, the intensity of competition fades as the value of the coefficient approaches zero, and is 0.14 out of 1 . Comparing the average distance between partner countries and the distance between the markets of Ukraine and the potential importing market, it is determined that the distance to the US, Canada, Japan, Brazil is greater than average, and therefore these markets can not be considered as new markets for exports of product group «1008 Buckwheat, millet and other cereals».

The markets of Austria and Nigeria have a low concentration of competition and acceptable distance of partner markets, so they can become new markets for the export of the product group «1008 Buckwheat, millet and other cereals» on the basis of «Distance between partner countries». The markets of the USA, Canada, Japan, Brazil are potential new markets in which the «Concentration of all importing countries of partner countries» indicator is low.

When choosing methods to assess the attractiveness of international markets, it is important that in the implementation of internationalization strategy, Ukrainian farmers can not be guided by universal solutions, because this process requires creativity to meet the requirements of a particular consumer in a particular market and time. Let's identify the most typical forms of marketing strategies by Ukrainian producers of the product group «1008 Buckwheat, millet and other cereals» in the markets of Austria and Nigeria by indicators of attractiveness of their business environment, which are important to consider for further development and implementation of internationalization strategy by Ukrainian buckwheat producers) (table 3).

Table 3: Evaluation of the attractiveness of the business environment of new international markets for Ukrainian agricultural producers by product group «1008 Buckwheat, millet and other cereals», 2018-2019

\begin{tabular}{|l|c|c|c|}
\hline Factor / foreign market & Year & Austria & Nigeria \\
\hline \multirow{2}{*}{ Economic growth, \% } & 2018 & 2,58 & 1,92 \\
\cline { 2 - 4 } & 2019 & 1,42 & 2,21 \\
\hline
\end{tabular}




\begin{tabular}{|c|c|c|c|}
\hline Factor / foreign market & Year & Austria & Nigeria \\
\hline \multirow{2}{*}{ GDP at current prices, billion dollars } & 2018 & 445,08 & 397,19 \\
\hline & 2019 & 445,08 & 448,12 \\
\hline \multirow{2}{*}{$\begin{array}{l}\text { GDP per capita at purchasing power parity, } \\
\text { thousand dollars / person }\end{array}$} & 2018 & 55474,20 & 5155,07 \\
\hline & 2019 & 56029,61 & 5135,50 \\
\hline \multirow{2}{*}{ Inflation rate (according to the consumer price index) } & 2018 & 2,0 & 12,1 \\
\hline & 2019 & 1,5 & 11,4 \\
\hline \multirow{2}{*}{ Household consumption, $\%$} & 2018 & 51,92 & 76,60 \\
\hline & 2019 & 51,70 & 73,49 \\
\hline \multirow{2}{*}{ Terms of trade, $\%$} & 2018 & 87,31 & 142,28 \\
\hline & 2019 & 85,99 & 168,42 \\
\hline \multirow{2}{*}{ Openness of trade, (exports + imports) $\%$ of GDP } & 2018 & 108,11 & 33,01 \\
\hline & 2019 & 107,78 & 34,02 \\
\hline \multirow{2}{*}{ Foreign direct investment, $\%$ of GDP } & 2018 & $-6,27$ & 0,50 \\
\hline & 2019 & $-1,82$ & 0,74 \\
\hline \multirow{2}{*}{ Government efficiency ratio } & 2018 & 1,45 & $-1,02$ \\
\hline & 2019 & 1,49 & $-1,09$ \\
\hline \multirow{2}{*}{ Corruption control ratio } & 2018 & 1,60 & $-1,05$ \\
\hline & 2019 & 1,55 & $-1,09$ \\
\hline \multirow{2}{*}{ Coefficient of quality of legislative regulation } & 2018 & 1,53 & $-0,8$ \\
\hline & 2019 & 1,46 & $-0,86$ \\
\hline \multirow{2}{*}{ Rule of law index, points } & 2018 & 1 & 3 \\
\hline & 2019 & 1 & 3 \\
\hline \multirow{2}{*}{ Index of business freedom, points } & 2018 & 76 & 49 \\
\hline & 2019 & 75 & 51 \\
\hline \multirow{2}{*}{ Freedom of trade index, points } & 2018 & 87 & 66 \\
\hline & 2019 & 86 & 62 \\
\hline \multirow{2}{*}{ Index of economic freedom, points } & 2018 & 72 & 59 \\
\hline & 2019 & 72 & 57 \\
\hline \multirow{2}{*}{ Share of agriculture in GDP, $\%$} & 2018 & 1,13 & 21,20 \\
\hline & 2019 & 1,09 & 21,90 \\
\hline \multirow{2}{*}{ Innovation index, points } & 2018 & 51,30 & 22,40 \\
\hline & 2019 & 50,90 & 23,90 \\
\hline \multirow{2}{*}{ Income tax rate, $\%$} & 2018 & 51,50 & 34,80 \\
\hline & 2019 & 51,40 & 34,80 \\
\hline \multirow{2}{*}{ Quality of life index } & 2018 & 7,14 & 5,16 \\
\hline & 2019 & 7,25 & 5,26 \\
\hline
\end{tabular}

Source: Compiled by the author for (Global Economy, Trade Statistics for International Business Development)

Analyzing the information offered by the World Bank, the Eurasian Development Bank, and forming indicators for assessing the feasibility of the chosen internationalization strategy by Ukrainian farmers, we will assess the attractiveness of the business environment of new international markets for Ukrainian buckwheat producers (table 4). A group of ten experts conducted a ranking based on the method of summing the ranks, previously identified as potential markets on a 5-point scale (rating scale). 
Table 4: Rating of international markets based on the method of summing the ranks of attractiveness indicators of their business environment for Ukrainian farmers by product group "1008 Buckwheat, millet and other cereals", 2018-2019

\begin{tabular}{|c|c|c|c|}
\hline Factor / foreign market & Year & Austria & Nigeria \\
\hline 1 & 2 & 3 & 4 \\
\hline \multirow{2}{*}{ Economic growth, \% } & 2018 & 3 & 2 \\
\hline & 2019 & 2 & 2 \\
\hline \multirow{2}{*}{ GDP at current prices, billion dollars } & 2018 & 3 & 3 \\
\hline & 2019 & 3 & 3 \\
\hline \multirow{2}{*}{$\begin{array}{l}\text { GDP per capita at purchasing power parity, } \\
\text { thousand dollars / person }\end{array}$} & 2018 & 4 & 1 \\
\hline & 2019 & 4 & 1 \\
\hline \multirow{2}{*}{ Inflation rate (according to the consumer price index) } & 2018 & 2 & 4 \\
\hline & 2019 & 2 & 4 \\
\hline \multirow{2}{*}{ Household consumption, $\%$} & 2018 & 3 & 4 \\
\hline & 2019 & 3 & 4 \\
\hline \multirow{2}{*}{ Terms of trade, $\%$} & 2018 & 2 & 4 \\
\hline & 2019 & 2 & 4 \\
\hline \multirow{2}{*}{ Openness of trade, (exports + imports) $\%$ of GDP } & 2018 & 4 & 2 \\
\hline & 2019 & 4 & 2 \\
\hline \multirow{2}{*}{ Foreign direct investment, $\%$ of GDP } & 2018 & 3 & 1 \\
\hline & 2019 & 3 & 1 \\
\hline \multirow{2}{*}{ Government efficiency ratio } & 2018 & 4 & 1 \\
\hline & 2019 & 4 & 1 \\
\hline \multirow{2}{*}{ Corruption control ratio } & 2018 & 4 & 1 \\
\hline & 2019 & 4 & 1 \\
\hline \multirow{2}{*}{ Coefficient of legislative regulation quality } & 2018 & 4 & 1 \\
\hline & 2019 & 4 & 1 \\
\hline \multirow{2}{*}{ Rule of law index, points } & 2018 & 1 & 3 \\
\hline & 2019 & 1 & 3 \\
\hline \multirow{2}{*}{ Index of business freedom, points } & 2018 & 4 & 2 \\
\hline & 2019 & 4 & 2 \\
\hline \multirow{2}{*}{ Freedom of trade index, points } & 2018 & 4 & 3 \\
\hline & 2019 & 4 & 3 \\
\hline \multirow{2}{*}{ Index of economic freedom, points } & 2018 & 4 & 3 \\
\hline & 2019 & 4 & 3 \\
\hline \multirow{2}{*}{ Share of agriculture in GDP, $\%$} & 2018 & 1 & 3 \\
\hline & 2019 & 1 & 3 \\
\hline \multirow{2}{*}{ Innovation index, points } & 2018 & 4 & 1 \\
\hline & 2019 & 4 & 1 \\
\hline \multirow{2}{*}{ Income tax rate, $\%$} & 2018 & 3 & 2 \\
\hline & 2019 & 3 & 2 \\
\hline \multirow{2}{*}{ Quality of life index } & 2018 & 5 & 3 \\
\hline & 2019 & 5 & 3 \\
\hline Total & & 123 & 92 \\
\hline
\end{tabular}

Source: compiled by the author for (Global Economy, Organization for Economic Cooperation and Development, World Economy. World Finance. World Markets). 
During the formation of the evaluation chart, the average, largest and smallest global value of each indicator was taken into account (1-2 - minimum value, 3-4 - average value, 5 maximum value), the summation method determined the total indicator of each market, the maximum value of which indicates more favorable conditions for domestic enterprises to enter it.

As a result of conducting a study by summing the ranks of the above indicators, it was found that the markets of Austria and Nigeria showed favorable conditions for doing business in them, which is a prerequisite for Ukrainian farmers to enter the markets of these countries with product group «1008 Buckwheat, millet and others cereals». That is, the application of this approach allowed to develop a target portfolio for further targeting the implementation of the strategy of internationalization by domestic producers of the product group «1008 Buckwheat, millet and other cereals» (table 5).

Table 5: Determining the marketing direction of the Ukrainian farmers' business under the conditions of international diversification *

\begin{tabular}{|l|}
\hline Name of product group \\
\hline 1.Evident opportunity for domestic enterprises to enter the markets \\
\hline USA, Canada, Japan, Brazil, Austria, Nigeria \\
\hline $\begin{array}{l}\text { 2. It is recommended that domestic companies study the prospects of entering the } \\
\text { markets }\end{array}$ \\
\hline Austria, Nigeria \\
\hline $\begin{array}{l}\text { 3. Markets have been identified in which convergent conditions have been created for } \\
\text { the entry of goods of domestic agricultural enterprises }\end{array}$ \\
\hline Austria, Nigeria \\
\hline
\end{tabular}

Source: developed by the author

Based on the results of the analysis of practical aspects of the functioning of agricultural enterprises and their associations, a scientific and methodological approach has been worked out to a comprehensive assessment of the convergence of agricultural enterprises of Ukraine under the conditions of international diversification. The proposed approach is based on the application of the summation of ranks method for ranking foreign markets on a system of dynamic indicators, which allowed to determine the marketing attractiveness of new international markets for domestic enterprises in these markets and assess their convergence.

As a result of the proposed approach, foreign markets have been identified, which demonstrate favorable conditions for doing business in them, which indicates the presence of convergent conditions, which is a prerequisite for the entry of domestic agricultural enterprises into the markets of these countries, as well as factors and criteria for management decisions implementation of the domestic agricultural enterprises activities under the conditions of international diversification.

It has been proved that the markets of Austria and Nigeria have shown favorable conditions for doing business in them, which indicates a significant convergence of the markets of these countries. To enter certain markets and not to lose a permanent competitive advantage, companies must combine different approaches - standardization (priority to indicators of their own production efficiency) and adaptation (marketing the specific needs of the markets of Austria and Nigeria). 
It is determined that the markets of Austria and Nigeria are promising for domestic enterprises in the presence of opportunities to overcome a significant gap in certain indicators, and namely: the markets of Austria and Nigeria have low quality regulation and also unfavorable investment conditions.

\section{Conclusion}

During the study of scientific and methodological approaches to determining the marketing attractiveness of international markets for agricultural products and assessing their convergence, it has been proved that the effectiveness of the assessing process of the convergence of international agricultural markets depends on existing differences, market growth rates and the chances of overcoming the gap. When expertly assessing the degree of convergence, the markets of foreign countries should be highlighted, the indicators of which are as close as possible to the economy of Ukraine, the result of the assessment will allow to draw conclusions about the marketing opportunities of domestic agricultural enterprises. Thus, as a result of the proposed approaches it is possible to identify foreign markets that show favorable conditions for doing business in them, which indicates the presence of convergent conditions, which is a prerequisite for the entry of goods of domestic agricultural enterprises in the markets of these countries. A study of international markets has revealed that the markets of Austria and Nigeria have shown favorable conditions to conduct business on them by Ukrainian agrarians of buckwheat. That is, the application of this approach allowed to develop a target portfolio for further targeting the implementation of the internationalization strategy by the manufacturer of the product group «1008 Buckwheat, millet and other cereals».

The prospect of further research is attractiveness of new international markets assess for Ukrainian agricultural producers by different product groups, systematic attractiveness ranking of their business environment, promoting the entry of domestic enterprises into new international markets.

\section{References}

Bedenkov A.R. (1998), Methods for assessing regional economic and social asymmetries. Regional socio-economic asymmetry and mechanisms for its alignment. M.: INSAN.

Luk'yanenko D.H., Poruchnyk A.M., Kolot A. M., Stolyarchuk A. M. (2011), Resources and models of global economic development: monograph. K: KNEU, 703 p.

United Nations Development Program. Human Development Report 2013. The Rise of the South: Human Progress in a Diverse World, 2013. The Rise of the South: Human Progress in a Diverse World, 2013 URL: http://hdr.undp.org/sites/default/files/hdr_2013_ru.pd .

Bogomolov O.T. (2012), Economics needs reliable indicators. Economic strategies. M.: Institute of Economic Strategies. Volume 1. P. 12-17.

Baltserovich L. (2015). About the reforms in Poland and Ukraine, URL: http://aillarionov.livejournal.com /784039.html.

Heyec' V. M. (2015). Overcoming quasi-market way to investment-oriented model of economic growth. Ukraine economy. Volume 6. P. 4-17.

Nort D. Institutions, institutional change and the functioning of the economy. K.: Osnovy, 2000. 198 p.

State building and socio-political situation. (2003), URL: http://mestectvo.com/istoriya-ukraini/ independense.html. 
Kovin'ko O. M. Marketing in the conditions of international diversification of business activity: monograph. K.: KNEU, 2017. 423 p.

Korol'chuk L. V. (2012), Economic convergence of regions as a necessary condition for deepening the processes of intensification of cooperation. P. 15-21. URL: http://eforumIntu.com/assets/files/articles/2012/3/28.pdf.

Luk'yanenko D.H., Chuzhykov V., Vozhnyak Mixal H (2013), Convergence and divergence in Europe: Polish and Ukrainian cases: monograph. K.:KNEU, 688 p.

Milovanov E. Diversification strategy is the basis of financial stability of a multidisciplinary consumer services enterprise. Problems of management theory and practice.2006. Volume 10. P. 96-104.

Barro Robert J., Xavier Sala-i-Martin Convergence I. II Journal of Political Economy. 1992, v. 100, No 2. P. $223-$ 251.

Durlauf S.N., Quah D.T. The New Empirics of Economic Growth I. II Handbook of Macroeconomics. Volume 1. Eddited by J.B. Taylor and M. Woodford. Elsevier, 1999. P. 235-308.

Mankiw G., Romer D., Weil D. A contribution to the empirics of economic growth I. II The Quarterly Journal of Economics. 1992. Vol. 107. P. 407-437.

Quah, D. Empirical cross-section dynamics in economic growth. II European Economic Review. 1993. № 37 (2/3). P. 426-434.

Sala-i-Martin X. The Classical Approach to Convergence Analysis. II The Economic Journal. 1996. v. 106 (July). P. 1019-1036.

Organization of economic cooperation and development. URL: http://www.oecdbetterlifeindex.org /countries /belgium/.

Novitskiy E.G. Strategic planning in highly diversified corporate structures: on the world practice and experience of Sistema. (1999), REZH, Volume 8. P. 72-78.

Walldorf G.E. Auslandsmarketing: Theorie und Praxis das Auslands gaeschaefts. Wiesbaden: Gaebler. (65/1). P. 20-21.

Kaplan R.S., Norton The Strategy Focused Organization. Boston: HBS Press, 2001.

Tanasiichuk A., Kovalchuk S., Hromova O., Hryhorenko I., Fedortsova O. «Evaluation of the Convergence of International Markets for Agricultural Enterprises of Ukraine under International Diversification Conditions», European Journal of Sustainable Development. Italy. 2020. Vol 9, No 2. p. 467-487 DOI: https://doi.org/10.14207/ejsd.2020.v9n2p467 .

Tanasiichuk A., Hromova O., Abdullaieva A., Kovtun E., Marshuk L. «Assessing the Convergence of International Agricultural Markets as a Prerequisite for Rapeseed Sale at New Markets», European Journal of Sustainable Development. Italy. 2021. Vol 10, No 1. p. 527-538. DOI: https://doi.org/10.14207/ejsd.2021.v10n1p527

Hudáková Stašová L. Statistical analysis of suitability of the activity based costing method in agricultural enterprises. Agricultural and Resource Economics. 2020. Vol. 6. No. 4. Pp. 20-42. URL: https://arejournal.com .

Ukrainian Club of Agrarian Business. URL: https://ucab.ua/ua/pres_sluzhba/novosti/za_20_rokiv_obsyagi _virobnitstva_grechki_v_ukraini_skorotilisya_v_46_raziv

Organization for Economic Cooperation and Development, World Economy. World Finance. World Markets. URL: https://www.trademap.org

Global Economy. URL: https://www.theglobaleconomy.com/compare-countries/

Newell E. Chiesl Ph.D. Steven W. Lamb Ph.D. Segmenting international industrial markets. Journal of the Academy of Marketing Science. 1983. Volume 11, pages250-258.

Bernard J. Jaworski, Fernando Robles, Adel El-Ansary. Book Review: Entry Strategies for International Markets. Journal of Marketing, vol. 52, 4: pp. 128-129. 1988.

Weihe Gao, Li Ji, Yong Liu, Qi Sun Branding Cultural Products in International Markets: A Study of Hollywood Movies in China. Journal of Marketing, vol. 84, 3: pp. 86-105. 2020.

Bart De Langhe, Stefano Puntoni, Daniel Fernandes, Stijn M.J. Van Osselaer. The Anchor Contraction Effect in International Marketing Research. Journal of Marketing Research, vol. 48, 2: pp. 366-380. 2011.

Sebastian Gabel, Daniel Guhl, Daniel Klapper. P2V-MAP: Mapping Market Structures for Large Retail Assortments. Journal of Marketing Research. vol. 56, 4: pp. 557-580. 2019. 